\title{
Deterministic Elements of Japanese Stock Prices under Low Interest Rates
}

\author{
Yutaka Kurihara $\mathrm{a}^{*}$ \\ a Aichi University, Nagoya, Japan. \\ *Corresponding author's email address: kurihara@vega.aichi-u.ac.jp
}

\section{A R T I C L E I N F O}

Received: 25-03-2016

Accepted: 22-04-2016

Available online: 05-05-2016

Keywords:

Exchange rate;

Japan; Stock price;

Zero interest rate policy.

JEL Classification:

E43; E52; G11; G12; G15.

\begin{abstract}
A B S T R A C T
This paper uses daily data to perform an empirical analysis of the relationship between recent Japanese stock prices and macroeconomic variables under the zero or low interest policy in Japan. The empirical results indicate that short-term interest rates have not impacted Japanese stock prices. On the other hand, long-term interest rates, exchange rates, and foreign stock prices have been significant determinants of Japanese stock prices. This seems counter to traditional economic theory, but interest rates were quite low and other variables, such as exchange rates and other stock prices, play important roles in determining Japanese stock prices.
\end{abstract}

(C) 2016 The Authors. This is an open access article under the terms of the Creative Commons Attribution License 4.0, which allows use, distribution and reproduction in any medium, provided the original work is properly cited.

DOI: http://dx.doi.org/10.18533/jefs.v4i02.224

\section{I.0 Introduction}

Starting in the 1990s, Japan experienced unprecedented recession and deflation. In that period, Japan conducted traditional, aggressive fiscal policy under severe budget constraints, and the Bank of Japan (BOJ; the Japanese central bank) conducted unprecedented zero or low interest rate policy. However, because these policies were not enough to cease deflation, since 2001, the BOJ has implemented quantitative easing. There is much dispute over whether or not quantitative easing has been effective and whether or not it achieved the current economic recovery.

Along with the intent to promote the yen's depreciation to expand exports, one of the purposes of the BOJ's policy seems to be to raise stock prices. The BOJ has not admitted this purpose; however, the governor of the BOJ has reiterated that it is important to increase the transfer of funds from safe to risky assets. The quantitative monetary easing policy is thought to be strongly related to this purpose. However, the effect of these policies, zero or low interest rate policy and quantitative easing policy on stock prices has not been discussed fully. Analysis of this effect is important because of its impact on the Japanese economic recovery, which has prevailed for more than 20 years. Japanese financial participants as well as companies are very interested in stock prices. Most large or exporting Japanese companies have enjoyed good economic performance; however, internal reserves have not changed into new investments and rising wages, so the Japanese economy has not recovered strongly.

This paper analyzes the deterministic elements of stock prices in Japan, particularly with regard to macroeconomic variables. In general, the most important element in determining stock prices has been interest rates all over the 
world as per economic theory. However, in Japan, market interest rates have been almost zero starting with implementation of the zero interest rate policy in 1999 and with the quantitative monetary easing policy beginning in 2001. Also, many developed economies have introduced low interest rate policies. The effect of changes in interest rates on stock prices may have been decreasing or negligible. Stock prices have risen under very low interest rates. Although this increase is not large, it seems important to examine the reason carefully. There may be other macroeconomic factors that affect stock prices. So this article examines what deterministic elements influence Japanese stock prices are. Zero or low interest rate policies have been implemented not only in Japan but also in other countries. For this reason, other factors present in foreign countries should be considered. Also, term structure of interest rates should be taken into account.

The following section examines the relationship between the Japanese stock markets and other markets. I then provide the theoretical framework of the analysis followed by application of the empirical method and analysis of the deterministic elements of stock prices in Japan. More concretely, section 2 reviews existing studies about the relationship between stock prices and macroeconomic variables. Section 3 provides theoretical analyses for later empirical analyses. Section 4 shows the empirical analyses and examines the results. Finally, the article concludes with a brief summary.

\subsection{Relationship between stock market and other macroeconomic factors}

The relationship between stock prices and macroeconomic variables has long been discussed all over the world. Campbell (1987, 1991), Campbell and Shiller (1998), Cutler, Poterba, \& Summers (1989), Fama and Schwert (1997) and Hodrick (1992) showed that short- and long-term interest rates have a modest degree of forecasting power for excess stock returns. Similarly, other studies, such as Campbell and Shiller (1991) and Fama (1984), have shown that the slope of the term structure of interest rates helps to forecast excess stock returns.

On the other hand, Campbell and Ammer (1993) and Hamori and Honda (1996) showed that short-term interest rates affect stock prices. During the 1980s and 1990s, many researchers analyzed the relationship between stock prices and interest rates. One reason seems that so-called normal interest rates are prevalent in Japan.

This paper discusses the elements of daily stock prices in Japan. Daily stock prices are determined by many elements, including enterprise performance, dividends, other countries' stock prices, gross domestic product (GDP), exchange rates, interest rates, current account, money stock, employment, and so on. Countless factors can impact stock prices.

It seems natural that the elements that influence stock prices change over time. For example, in 1970s and early 1980s, inflation rates were high all over the world, which impacted stock prices. Since then, in general, interest rates have had much influence on stock prices. This paper focuses on the recent period, especially after the quantitative easing. Note that interest rates have been quite low, as indicated by the term zero interest rate. Also, many developed countries have employed low interest rate policies. It is uncertain whether the interest rate has had an effect on stock prices. There is some possibility that other factors have been more influential than the interest rates.

Black Monday occurred in 1987 in the United States. Stock prices drop tremendously all over the world. At that time, the international interdependence of stock prices received much attention, which prompted studies by Eun and Shim (1989), Jeon and Chiang (1991), Lai, Lai, \& Fant (1993), Chowdhury (1994), and Hirayama and Tsutsui (1998). Liow, Muhammad, and Huang (2006) showed that the expected risk premium and the conditional volatilities of the risk premium on property stock are time-varying and dynamically linked with the conditional volatilities of macroeconomic factors. However, there are few recent studies on the topic. Meric (2012) showed that US stock markets largely influence the European and Australian stock markets. Also, Meric, Kimb, Geng, and Meric (2012) indicated that Singapore, Indian, and Japanese stock markets are the most influential markets and the Philippine and South Korea stock markets are the least influential stock markets in Asia. Mazuruse (2014) found that stock returns in Zimbabwe are most largely influenced by the changes in consumer price, money stock, exchange rate, and Treasury bill. Pradhan, Arvin, Norman, and Hall (2014) showed that banking sector maturity and stock market maturity are causally linked.

Little research exists on the effect of the exchange rate on stock prices. Hamao (1988) investigated this relationship and found that the exchange rate was insignificant for Japan, but Choi, Hiraki, \& Takezawa (1998) reported that the exchange rate is an important factor. Homma, Tsutsui, and Benzion (2005) stated that stock investors evaluate firms' foreign asset positions and respond to changes in exchange rate. Demarzo and Duffie (1995), Barton (1996), Brown (2001), and Pincus and Rajgopal (2003) argued that hedging using derivatives can reduce the amount of noise in corporate earnings. Since the 1980s, capital movement across countries has been 
dramatic. In spite of the reduction in fluctuations of the exchange rate in the 1990s compared to the 1980s, the movement should not be ignored. From the middle of the 2000s, exchange rate instability has been prevalent. In the latter half of the 2000s, exchange rates fluctuated greatly. There is some possibility that exchange rate has been influencing Japanese stock prices.

The influence of macroeconomic variables and relationships among them have been changing constantly, as noted above. Under such circumstances, theoretical analysis is important; however, the research must rely on empirical analysis. Not only Japanese data but also data from other countries are included for estimations. Some empirical analyses, for example, VAR are employed to examine the deterministic elements of Japanese stock prices.

There is some dispute about statistical properties. For the last 10 years or so, empirical and statistical methods have improved rapidly. Above all, time series analysis has improved greatly. The unit root test, for example, has become popular and necessary to estimation. This paper therefore differs from most past studies in the empirical methods. Also, data availability has changed. This paper uses daily data. Some past studies on this topic have used quarterly or monthly data.

In academic fields, most studies have used rates of stock prices, which are more suitable for measuring the effects of some kinds of shocks and events. However, in the real world, price differences are more important to trade in many cases. Changes of data are used for both academic-interest oriented and investor-interest oriented approaches.

Because these events are fairly recent, few studies have addressed this issue. Some papers have dealt with only the era of quantitative easing; however, few studies have been done for the era of zero or low interest rate policy. However, it seems important to examine the effectiveness of the zero or low interest rate policy. The findings can be useful in providing policy implications.

\subsection{Theoretical framework}

\subsection{Empirical method for analysis}

This paper starts with the unit root tests of all of the variables. For this purpose, an augmented Dickey-Fuller (ADF) statistical test is used to determine whether the series is stationary. Standard inference procedures do not apply to regressions that contain an integrated dependent variable or integrated regressors. Therefore, it is important to determine whether or not a series is stationary. To do this, it is necessary to change some variables from nonstationary to stationary time series and calculate a regression.

Following the ADF statistical test, the present approach uses a cointegration test. It is known that a linear combination of two or more nonstationary time series may be stationary. Also, most financial data (except interest rates) are not stationary. If such a stationary linear combination exists, the nonstationary time series is said to be cointegrated. The stationary linear combination is interpreted as a long-run equilibrium relationship among the variables.

After that, the vector error correction (VEC) model is used. This model is a restricted VAR designed for use with nonstationary series that are known to be cointegrated. The VEC has cointegration relations in the specification so that it restricts the long-run movement of the endogenous variables to converge to their cointegrating relationships while allowing for short-run adjustment dynamics. The next step is impulse responses. A shock to the $\mathrm{i}$-th variable not only directly affects the $\mathrm{j}$-th variable but is also transmitted to all of the other endogenous variables by the dynamic (lag) structure of the VAR. The impulse response function traces the effect of a one-time shock to one of the movements on current and future values of the endogenous variables.

\subsection{Relationships among variables}

Economic theory in general provides firm concepts for macroeconomic variables as related to stock prices. Stock prices are thought to be influenced not only by dividends and future expectations for the issuing company's performance but also by macroeconomic variables. Traditional research has indicated that an interest rate increase (or decrease) usually induces the decline (or increase) of stock prices. However, empirical studies have provided various results. For example, when economic recovery is too strong, the effect of rising interest rates on stock prices occurs. In the case of interest rates in foreign countries, the influence on domestic stock prices is complicated. Usually, rising foreign interest rates induce a decrease in that country's stock prices, and as a result, domestic stock prices decrease. However, there is some possibility that depreciation of domestic currency by high foreign interest rates may increase domestic stock prices. It is difficult to determine whether changes in the 
exchange rate produce a positive or negative effect. It can be said clearly, however, in an export-oriented country such as Japan, that depreciation of the currency increases exports and raises stock prices. In analyses of recent stock price fluctuations, exchange rate movements seem to be an inevitable factor to consider stock prices movements because large volumes of capital move every day, not only for international trade but also for capital investment.

Finally, oil prices have started to influence stock prices. Oil exporting countries have been influenced much as oil prices move. Oil prices impact economic conditions in oil exporting countries and have become an element in the determination of income in oil exporting countries and Japanese stock prices.

\subsection{Stock price and macroeconomic variables}

\subsection{Overview and sample period}

As mentioned above, the purpose of this study is to analyze recent stock prices in Japan. The bubble economy collapsed in 1991 and recession started in 1992. Since 1992, the Japanese government and the BOJ have implemented drastic policies to overcome recession. On March 19, 2001, the quantitative easing policy started. This policy ended in 2006; however, low interest policies have been used continuously. Since 2013, quantitative and qualitative monetary easing policy have been in effect. This paper analyzes the recent periods using time series analysis in this section. The sample period is from the start of 2007 to the end of 2015.

\subsection{Empirical analysis}

4.2.1 Unit root tests. First, the unit root of each variable related to stock prices is checked. The variables estimated are Japanese stock price (Nikkei average: stockJ), US stock price (DOW, S\&P, DAX, and SHA[China]), exchange rate (yen/US dollar: excus and yen/Euro: exceu), Japanese call (interest) rate (call), Japanese 10 years treasury rate (10yint), FF rate (FF), and oil price (oil). The test method is ADF. Table 1 provides the results.

\begin{tabular}{lrrr}
\hline \multicolumn{4}{c}{ Table 1. Unit root tests of each variable } \\
\hline Variable & $\mathrm{t}$-Value & First-Order Difference & $\mathrm{t}$-Value \\
\hline stockJ & -1.037 & $\Delta$ stockJ & -46.450 \\
DOW & -0.577 & $\Delta$ DOW & -47.335 \\
S\&P & -0.446 & $\Delta$ S\&P & -46.651 \\
DAX & -0.774 & $\Delta$ DAX & -43.677 \\
SHA & -1.595 & $\Delta$ SHA & -44.045 \\
excus & -1.042 & $\Delta$ excus & -45.544 \\
exceu & -1.618 & $\Delta$ exceu & -48.262 \\
call & -1.090 & $\Delta$ call & -25.805 \\
10yint & -1.205 & $\Delta 10$ yint & -47.319 \\
FF & -3.660 & $\Delta$ FF & -10.284 \\
oil & -0.962 & $\Delta$ oil & -47.403 \\
\hline Note. Significant levels at $10 \%, 5 \%$, and $1 \%$ are $-2.567,-2.863$, and -3.433. & \\
\hline
\end{tabular}

As shown in the table, one of the three interest rates (FF) are significant (at 1\%); however, the other variables, excluding some differences of interest rates, are not significant. All of the lagged variables and variable rates are significant at $1 \%$. All of the variables that take lagged first difference are stationary.

4.2.2 Regression analysis. Using these results, Japanese stock prices are regressed by the US stock price, exchange rate, and interest rates. Table 2 provides the variables of the estimation equations and the estimated results by OLS. Equation (2) shows the results when insignificant variables are omitted from equation (1).

\begin{tabular}{|c|c|c|}
\hline & Coefficient & Coefficient \\
\hline C & $\begin{array}{r}1.078 \\
(0.311)\end{array}$ & $\begin{array}{r}1.128 \\
(0.326)\end{array}$ \\
\hline$\triangle \mathrm{DOW}$ & $\begin{array}{r}0.463^{* * *} \\
(8.472)\end{array}$ & $\begin{array}{r}0.463^{* * *} \\
(8.493)\end{array}$ \\
\hline$\Delta \mathrm{S} \& \mathrm{P}$ & $\begin{array}{r}1.010 \\
(0.990)\end{array}$ & \\
\hline$\triangle \mathrm{DAX}$ & $\begin{array}{r}0.360^{* * *} \\
(8.620)\end{array}$ & $\begin{array}{l}0.378^{* * *} \\
(11.521)\end{array}$ \\
\hline$\Delta \mathrm{SHA}$ & $\begin{array}{r}-0.100 \\
(-0.839)\end{array}$ & \\
\hline$\Delta$ excus & $\begin{array}{r}89.873^{* * *} \\
(15.095)\end{array}$ & $\begin{array}{r}90.173^{* * *} \\
(15.207)\end{array}$ \\
\hline
\end{tabular}




\begin{tabular}{|c|c|c|}
\hline$\Delta$ exceu & $\begin{array}{r}43.925^{* * *} \\
(11.922)\end{array}$ & $\begin{array}{r}43.992^{* * *} \\
(11.997)\end{array}$ \\
\hline$\Delta$ call & $\begin{array}{r}-231.972 \\
(-1.215)\end{array}$ & \\
\hline$\Delta 10 y i n t$ & $\begin{array}{r}979.185^{* * *} \\
(6.525)\end{array}$ & $\begin{array}{r}981.911^{* * *} \\
(6.559)\end{array}$ \\
\hline$\Delta \mathrm{FF}$ & $\begin{array}{r}4.003 \\
(0.128)\end{array}$ & \\
\hline$\Delta$ oil & $\begin{array}{r}6.619^{* * *} \\
(2.999)\end{array}$ & $\begin{array}{r}6.623^{* * *} \\
(3.015)\end{array}$ \\
\hline F-statistic & $183.467^{* * *}$ & 305.529 \\
\hline D.W. & 2.383 & 2.381 \\
\hline Adj.R2 & $\begin{array}{r}0.483 \\
\text { (1) }\end{array}$ & $\begin{array}{r}0.483 \\
(2)\end{array}$ \\
\hline
\end{tabular}

The results of equations (1) and (2) are almost clear and they show some interesting points. First, interest rates, except for 10-year treasury bonds, are not significant. This fact is counter to traditional economic/finance theory. The reason is that interest rates in developed countries are quite low, which reflects financial authorities' desire to promote lending and investment. However, domestic long-term interest rates are still one of the indicators of stock prices. Second, instead of interest rates, stock prices correlate with each other in the cases of the DOW and DAX. Also, exchange rates impact stock prices as expected. Depreciation of the yen influences stock prices as depreciation may be considered to promote exports.

\subsection{Cointegration test}

As indicated in the unit root tests above, variables other than one interest rate are not stationary. In recent standard econometrics, cointegration is checked in this case. The finding that many macro time series may contain a unit root has caused the development of the nonstationary time series analysis. A linear combination of two or more nonstationary series are said to be cointegrated. The stationary linear combination may be interpreted as a long-run equilibrium relationship among the variables.

\subsection{Impulse responses}

An impulse response function traces the effect of a one-time shock to one of the innovations on current and future values of the endogenous variables. The model and the results are shown in Table 3(one time difference).

\begin{tabular}{lrr}
\hline & Table 3: VER model for impulse response function & \\
\hline & $\Delta$ stockj & $\Delta$ DOW \\
\hline c & -1.022 & 0.014 \\
& $(-0.243)$ & $(0.009)$ \\
stockj(-1)-stockj(-2) & $-0.257^{* * *}$ & $0.019^{* *}$ \\
& $(-8.927)$ & $(1.869)$ \\
stockj(-2)-stockj(-3) & -0.022 & -0.002 \\
& $(-0.842)$ & $(-0.227)$ \\
DOW(-1)-DOW(-2) & -0.003 & 0.0045 \\
& $(-0.057)$ & $(0.192)$ \\
DOW(-2)-DOW(-3) & -0.011 & -0.009 \\
& $(-0.168)$ & $(-0.418)$ \\
SHA(-1)-SHA(-2) & $0.708^{* * *}$ & $0.085^{* * *}$ \\
& $(24.316)$ & $(8.493)$ \\
SHA(-2)-SHA(-2) & $0.176^{* * *}$ & $0.031^{* *}$ \\
& $(5.295)$ & $(2.714)$ \\
excus(-1)-excus(-2) & $28.146^{* * *}$ & 4.175 \\
excus(-2)-excus(-2) & $(3.630)$ & $(1.557)$ \\
& -12.272 & 0.854 \\
exceu(-1)-exceu(-2) & $(-1.592)$ & $(0.320)$ \\
& -0.793 & -2.599 \\
exceu(-2)-exceu(-2) & $(-0.178)$ & $(-1.688)$ \\
10yint(-1)-10yint(-2) & 3.779 & -1.535 \\
10yint(-2)-10yint(-3) & $(0.854)$ & $(-1.002)$ \\
Adj.R2 & -196.628 & -94.255 \\
F-statistic & $(-1.062)$ & $(-1.472)$ \\
Akaike AIC & $356.693^{* *}$ & 64.254 \\
Note. Parenthetical figures in the table are the t values. & $(1.940)$ & $(1.010)$ \\
& 0.240 & 0.031 \\
& $52.477^{* * *}$ & $6.726^{* * *}$ \\
& 13.288 & 11.164 \\
\hline
\end{tabular}


Based on Tables 3, the impulse response function is as shown in Figure 1.

Figure 1: Impulse response function

Response to Cholesky One S.D. Innovations \pm 2 S.E.
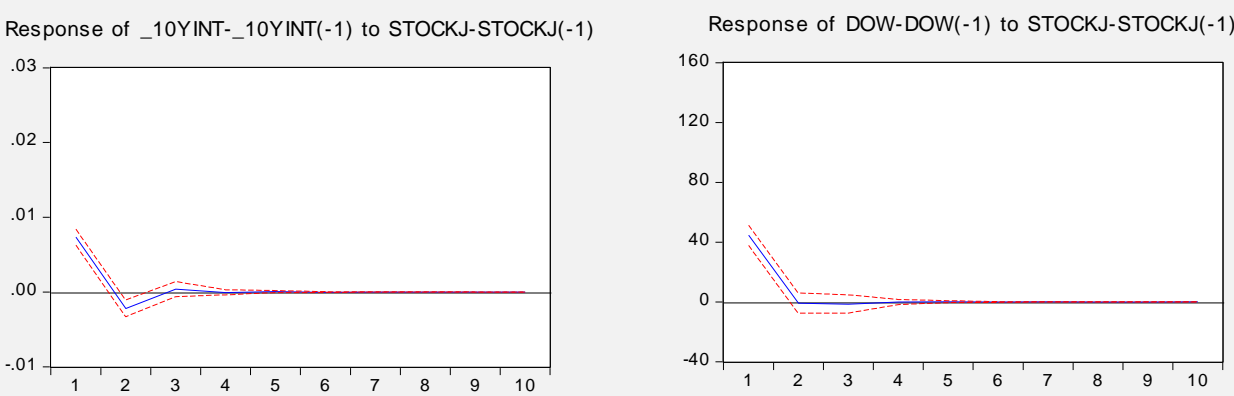

Response of EXCUS-EXCUS(-1) to STOCKJ-STOCKJ(-1)
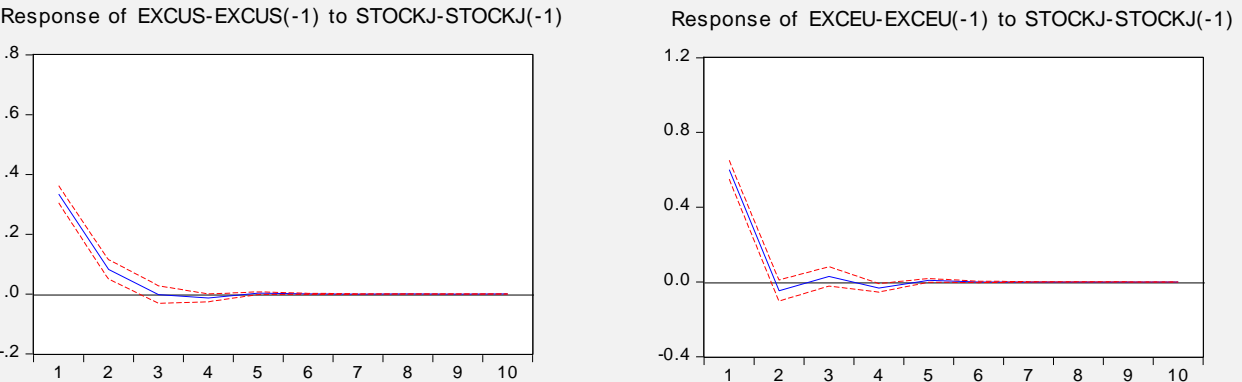

The results show that if US stock prices rise, Japanese stock prices rise next day. However, the shock will extinguish in a week. The effect on Japanese stock prices is the same with the exchange rate. Depreciation of the Japanese yen causes increases in Japanese stock prices; however, the effect will extinguish in a week or so.

\subsection{Conclusion}

This paper examined the era of the zero or low interest rate policy. Focusing only quantitative easing policy is important as this policy is drastic; however, this analysis indicates important issues for policymakers. Applicable cases are much more than the cases of quantitative easing policy in other countries. Also, the results of empirical studies have provided important information. Above all, interest rates have not influenced Japanese stock prices. Instead, exchange rates and stock prices of other countries have large impacts on Japanese stock prices. Of course, it is in reality impossible to control exchange rates and other countries' stock prices; however, policymakers should carefully consider these factors in some cases.

Moreover, other empirical methods, for example ARDL (auto regressive distributed lags) would be useful as ADF tests are not sometimes certain. However, such analyses performed for this study did not provide clear results. Finally, this analysis is thought to be a reduced-form analysis. Structural model(s) in the analysis are in the socalled black box. I offered some important and suggestive points for stock prices; however, this problem also should be considered carefully. Furthermore, it would be interesting to investigate the efficiency of stock markets in terms of the speed of reaction if it were possible to determine returns for every minute, for example. These are, however, reserved for future study.

\section{Acknowledgements}

I highly appreciate the valuable comments and suggestions of the editor and the referee. I was supported by JSPS KAKENHI Grant Number 15 H03366 for this work.

\section{References}

Barton, R. J. (1996). Does the use of financial derivatives affect earnings management decisions? Accounting Review, 76, 1-26. http://dx.doi.org/10.2308/accr.2001.76.1.1

Brown, G. W. (2001). Managing foreign exchange risk with derivatives. Journal of Financial Economics, 60, 401448. Retrieved from http://dx.doi.org/10.1016/S0304-405X(01)00049-6

Campbell, J. Y., (1987). Stock returns and the term structure. Journal of Financial Economics, 18, 373-399. http://dx.doi.org/10.1016/0304-405X(87)90045-6 
Campbell, J. Y. (1991). A variance decomposition for stock returns. Economic Journal, 101, 157-179. Retrieved from http://10.2307/2233809

Campbell, J. Y., \& Ammer, J. (1993). What moves the stock and bond markets? A variance decomposition for longterm asset returns. Journal of Finance, 48(1), 3-37. http://dx.doi.org/10.1111/j.1540-6261.1993.tb04700.x

Campbell, J. Y., \& Shiller R. J. (1991). Yield spreads and interest rate movements: A bird's eye view. Review of Economic Studies, 58, 495-514. http://dx.doi.org/10.2307/2298008

Campbell, J. Y., \& Shiller, R. J. (1998). The dividend-price ratio and expectations of future dividends and discount factors. Review of Financial Studies, 1, 195-228. Retrieved from http://10.1093/rfs/1.3.195

Chadha, J. H., Sarno, L., \& Valente, G. (2004). Monetary policy rules, asset prices, and exchange rates. IMF Staff Paper, 51(4), 1-23.

Choi, J. J., Hiraki, T., \& Takezawa, N. (1998). Is foreign exchange rate risk priced in the Japanese stock market? Journal of Financial and Quantitative Analysis, 33, 361-382. Retrieved from http://10.2307/2331100

Chowdhury, B. (1994). Stochastic trends and stock prices: An international inquiry. Applied Financial Economics, 4, 383-390. http://dx.doi.org/10.1080/758518670

Cutler, D. M., Poterba J. T., \& Summers, L. H. (1989). What moves stock prices, Journal of Portfolio Management, 15, 4-12. Retrieved from http://10.3386/w2538

Demarzo, P., \& Duffie, D. (1995). Corporate incentives for hedging and hedge accounting. Review of Financial Studies, 8, 743-771. Retrieved from http://10.1093/rfs/8.3.743

Eun, C. S., \& Shim, D. (1989). International transmission of stock market movements. Journal of Financial and Quantitative Analysis, 24, 241-256. http://dx.doi.org/10.2307/2330774

Fama, E. F. (1984). The information in the term structure. Journal of Financial Economics, 13, 509-528. Retrieved from http://10.1016/0304-405X(84)90013-8

Fama, E. F., \& Schwert, W. G. (1997). Asset returns and inflation. Journal of Financial Economics, 5, 115-146. Retrieved from http://10.1016/0304-405X(77)90014-9

Hamao, Y. (1988). An empirical examination of the arbitrage pricing theory: Using Japanese data. Japan and the World Economy, 1, 45-61. Retrieved from http://10.1016/0922-1425(88)90005-9

Hamori, S., \& Honda, Y. (1996). Interdependence of Japanese macroeconomic variables. In Y. Ttutsui (Ed.), Japanese Capital Markets. Tokyo, Japan: Nihon-Hyoronsha (in Japanese).

Hirayama, K., \& Tsutsui, Y. (1998). Threshold effect in international linkage of stock prices. Japan and World Economy, 10, 441-453. http://dx.doi.org/10.1016/S0922-1425(98)00021-8

Hodrick, R. J. (1992). Dividend yields and expected stock returns, alternative procedures for inference and measurement. Review of Financial Studies, 5, 357-386. Retrieved from http://10.1093/rfs/5.3.351

Homma, T., Tsutsui, Y., \& Benzion, U. (2005). Exchange rate and stock prices in Japan. Applied Financial Economics, 15, 469-478. http://dx.doi.org/10.1080/09603100500056668

Jeon, B. N., \& Chiang T. C. (1991). A system of stock prices in world stock exchange: Common stochastic trends for 1975-1990. Journal of Economics and Business, 43, 329-338. Retrieved from http://10.1016/01486195(91)90029-V

Liow, K. H., Muhammad, F. I., \& Huang, Q. (2006). Macroeconomic risk influences on the property stock market. Journal of Property Investment and Finance, 24(4), http://dx.doi.org/10.1108/14635780610674507

Lai, M., K. Lai, S., \& Fang, H. (1993). Dynamic linkages between the New York and Tokyo Stock Markets: A vector error correction analysis. Journal of International Financial Markets, Institutions and Money, 3, 73-96. Retrieved from http://10.1300/J282V03N02_04

Mazuruse, P. (2014). Canonical correlation analysis: Macroeconomic variables versus stock returns. Journal of Financial Economic Policy, 6(2), 196-179. Retrieved from http://dx.doi.org /10.1108/JFEP-09-2013-0047

Meric, G. (2012). International evidence on market linkages after the 2008 stock market crash. The International Journal of Business and Finance Research, 6(4), 45-57.

Meric, I., Kimb, J. H., Geng, L., \& Meric, G. (2012). Co-movements of and linkages between Asian stock markets. Bulletin and Economics Research, 3(1), 1-15.

Pincus, M., \& Rajgopal, S. (2003). The interaction of accounting policy choice and hedging: Evidence from oil and gas firms. Accounting Review, 77, 127-160. Retrieved from http://dx.doi.org/10.2308/ accr.2002.77.1.127

Pradhan, R. P., Arvin, M. B., Norman, N. R., \& Hall, J. H. (2014). The dynamics of banking sector and stock market maturity and the performance of Asian economics: Time series evidence. Journal of Economics and Administrative Sciences, 30(1), 16-44. http://dx.doi.org/10.1108/JEAS-06-2013-0022 